Kastamonu Eğitim Dergisi
$\begin{aligned} & \text { Kastamonu Education Journal } \\ & \text { Ocak } 2020 \text { Cilt:28 Sayı:1 } \\ & \text { kefdergi.kastamonu.edu.tr }\end{aligned}$

\title{
Türkiye'de İngilizce Öğretim Programının Değerlendirilmesi: Beceri ve Ödev Önerileri üzerine Bir Çalışma1
}

\section{Evaluating EFL Curricula in Turkey: A Study on Skills and Suggested Assignments}

\author{
Reyhan AGCAM² \& Muzaffer Pınar BABANOĞLU³
}

Öz

Türkiye'de 2012 yılında gerçekleşen eğitim reformunun ardından, İngilizce dersi öğretim programı, Avrupa Dilleri Ortak Çerçeve Programı temelinde 2017 yılında güncellenerek takip eden eğitim-öğretim yılında uygulanmaya başlanmıştır. Programda, önceliğin; okuma ve yazma gibi geleneksel olarak vurgulanan becerilerden ziyade iletişimsel becerilere verildiği belirtilmektedir. Bu çalışmada, güncellenen öğretim programında tanımlı kazanımlar ile ödev önerilerinin, programın iletişimsel amaçlarına ne ölçüde hizmet ettiği araştırılıştır. Veriler, Milli Eğitim Bakanlığı'nın resmi internet sayfasında yayınlanmış bulunan İngilizce dersi öğretim programından elde edilmiş ve içerik analizi yöntemiyle çözümlenmiştir. Araştırma bulguları, kazanımların \%86'sının konuşma ve dinleme becerilerini geliştirmeye yönelik tasarlandığını ve programın iletişimsel yapısı ile uyumlu olduğunu göstermiştir. Ödev önerilerinin ise, programın temel felsefesinin aksine, öğrenciler arasında işbirliği ve iletişim gerektirmediği, \%76'sının öğrencilerin bireysel çabası temelinde yapılandırıldığı ortaya çıkmıştır. Çalışmanın, araştırmaya dayalı uygulama önerileri ile mevcut alan yazına katkı sağlayacağı düşünülmektedir.

Anahtar Kelimeler: ingilizce öğretim programı, iletişimsel beceri, kazanım, ödev

\section{Abstract}

Subsequent to the 2012 educational reform in Turkey, English as a Foreign Language course curriculum was revised based on the Common European Framework of Reference for Languages (CEFR) in 2017, and put into practice in the following academic year. It is acknowledged in the programme document that the primary focus is on the communicative skills rather than traditionally emphasized skills such as reading and writing. The current research primarily investigated the learning outcomes and suggested assignments identified in the primary EFL curriculum to see to what extent they are designed to attain communicative objectives of the programme. The data were compiled from the programme document released on the official website of Ministry of National Education (MoNE), and administered to content analysis. The research findings displayed that $86 \%$ of the learning outcomes were designed to improve speaking and listening skills, indicating compatibility of the communicative nature of the programme. The suggested assignments were, on the contrary to the major philosophy of the programme, not designed to require collaboration and communication between and among the students since $76 \%$ of them were grounded on their individual work. The study is intended to contribute to the existing literature via research-driven implications reported here.

Keywords: EFL curriculum, communicative skill, learning outcome, assignment

\footnotetext{
1 Preliminary findings of the study were orally presented in ECER 2018: The European Conference on Educational Research, held in Bolzano, Italy, on 4-7 September 2018.

${ }^{2}$ Kahramanmraş Sütçü İmam Üniversitesi Kahramanmaraş, Türkiye, http://orcid.org/0000-0002-5445-9031

${ }^{3}$ Mersin Üniversitesi, Gazi Eğitim Fakültesi, Mersin, Türkiye

Atıf / Citation: Agcam, S., ve Babanoğlu, M, P. (2020). Türkiye'de İngilizce Öğretim Programının Değerlendirilmesi: Beceri ve Ödev Önerileri üzerine Bir Çalışma. Kastamonu Education Journal, 28(1), 431-441. doi:10.24106/kefdergi.3635
} 


\section{Extended Abstract}

Introduction: Turkey entertained a major educational reform in 2012, which entailed a transition from $8+4$ system to $4+4+4$ system. Subsequent to this change, English as a Foreign Language course curriculum was revised based on the Common European Framework of Reference for Languages (CEFR) in 2017, and put into practice in the following academic year. It is acknowledged in the programme document that the primary focus is on the communicative skills rather than traditionally emphasized skills such as reading and writing. The rationale behind that statement is to raise students who will be able to use the target language for meaningful and communicative purposes in real life situations. The revised programme was evaluated by several scholars from different perspectives (Altan, 2017; Arıkan, 2017; Erdem, \& Yücel-Toy, 2017; Kurt, 2017; Yücel et al., 2017; Aksoy et al., 2018; Canlıer \& Tümen, 2018; Fişne et al., 2018). However, to the best of the researcher's knowledge, no study has previously evaluated the whole curriculum (2nd to 8th grades) with a focus on learning outcomes and suggested assignments regarding the communicative objectives of the programme. So, in order to bridge the research gap, the current research primarily investigated the learning outcomes and suggested assignments identified in the primary EFL curriculum to see to what extent they were designed to attain communicative objectives of the programme.

Method: Two sets of data were compiled from the programme document released on the official website of Ministry of National Education (MoNE): Learning outcomes and suggested assignments. The former set was analysed to see whether the communicative skills (speaking and listening) were really emphasized over other skills such as reading and writing. The latter set was examined the nature of suggested assignments to reveal to what extent they require collaboration/ cooperation and communication between and among students. The findings were obtained through content analysis.

Result: The research findings displayed that $86 \%$ of the learning outcomes were designed to improve speaking and listening skills, indicating high compatibility with the communicative nature of the programme. This finding largely overlaps with the existing literature (Jin \& Cortazzi, 2002; Mackenzie, 2002; Mihai, 2003; Koç, Işıksal \& Bulut, 2007; Kırkgöz, 2008; Orafi \& Borg, 2009; Banegas, 2011; Zhang, 2012; Dubetz, 2014; Kırkgöz, Çelik \& Arıkan, 2014; Altan, 2017; Yücel et al., 2017). The suggested assignments, on the contrary to the major philosophy of the programme, were not designed to require communication between and among the students since $76 \%$ of them were grounded on individual work. This finding is also in compatible with previous findings reported in Wallinger (1997) and Orafi (2008).

Conclusion: Based on the research findings, it could be concluded that the revised EFL curriculum bares some discrepancies between the suggested assignments and communicative objectives as well as highlighted skills (speaking and listening) in the programme. As for practical implications, the curriculum designers might be recommended to take the overall objective of the programme and teachers' views into account while outlining assignments in the curriculum. More specifically, assignments that promote collaboration/ cooperation among students and that encourage them to use the newly learnt language for communicative purposes might be integrated into the related curriculum. The curriculum designers might also be suggested to track scientific research conducted on curriculum and instruction at home and abroad, and to consider their results especially when they are supposed to revise a curriculum. Finally, EFL teachers could be suggested to develop their own teaching strategies and to modify the suggested assignments to overcome the weaknesses of the curriculum. The study was restricted to the investigation of the 2017EFL curriculum in Turkey with a focus on communicative objectives of the programme through document analysis method. In order to provide a better insight into the field, further studies might explore EFL curricula introduced at different levels of education in other countries through different data collection tools and analysis techniques. 


\section{Introduction}

In order to raise individuals needed for information society, taking individual differences such as capacity to learn, learning power, affective features and competences into account (Tezci, 2002), preparation of the physically and technologically wellequipped learning environments and contemporary teaching programmes that meet the requirements of the age came to agenda (Doğan, 2010). Hence, school curricula should be differentiated, enriched and designed to uncover interests, talents and potential of the students (Doğan \& Çetin, 2018) since making them aware of their potential and needs will contribute to their selfactualization allowing them to use their strengths in appropriate fields (Doğan \& Yıldırım, 2019). These mostly result in educational reforms and curriculum revisions in most countries regardless of their development level. In this concern, O'Neill (2010, p. 61) reported that 'curriculum revision tends to benefit from initial, intensive dialogue between educational developers and academic staff, and that such initial interaction provides an important understanding of the context in which it occurs'. Due to its widespread use in various fields ranging from business and trade to dissemination of scientific developments and results of academic research as a lingua franca, English is probably the subject of which curriculum is revised more frequently than the others especially in primary education. Turkey is no exception in this sense as it has paid special attention to English language learning and teaching 'to maintain its communication with other countries and sustain its competitiveness in many fields in which English plays a crucial role (Kırkgöz, 2008, p. 311). Concerning the failure in learning English, Dubetz (2014, p. 104) advocate that 'foreign language programs in public schools have not achieved this in practice that although the national foreign language standards reflect a commitment to developing learners' ability to use a foreign language for communicative purposes'. The researchers note that the limited success of young adults in attaining communicative proficiency in English by the end of high school might be triggered by various factors as poor instructional materials, large classes, limited English proficiency of EFL teachers, the lack of a coherent scope and sequence for EFL curriculum, and an emphasis on grammar and translation in most college entrance exams. Strakšiene (2011, p. 126) advocates that pupils have to get involved in the learning activity through studying, purposeful accumulation of information, completion of practical creative assignments, and presenting their outcomes to others since listening to teacher's explanation or watching demonstration alone will not suffice for the acquisition of the communicative competence. Therefore, the researcher argues that development of this competence should start in early schooling. In this concern, Johnstone (2009) asserts that the introduction of English as a compulsory subject at younger and younger ages is 'possibly the world's biggest policy development in education' (p. 33). Noting that the 1996 curriculum reform in Thailand required introduction of English from the very beginning of primary education with an initial focus on listening and speaking, Mackenzie (2002) reported significant improvement of students' communicative abilities in the target language after the implementation of the new curriculum. In Romanian context, Mihai (2003) remarks that the first attainment target identified in the revised EFL curriculum for 3rd to 9th grade subsequent to the 2001 education reform was the development of the ability to understand oral messages in the target language, followed by the ability to oral expression, ability to written expression, ability to understand cultural representations and of an interest for the study of English language and Anglo-Saxon civilization. Likewise, Orafi and Borg (2009) inform that EFL curriculum for secondary education in Libya was revised in 2000 to "develop students' oral communication skills" (p. 251). It was stated in the 2003 EFL curriculum in Spain that 'the approach to be adopted was the communicative approach and that the main aim was to develop students' communicative competence through skills, socio-pragmatic competence and linguistic competence' (Banegas, 2011, p. 421). In Mexico, on the other hand, the EFL curriculum in public lower secondary schools has been based on a communicative language teaching approach since the 1990s, with a major focus on primary school students' engagements, especially through music, movies, and video games to accomplish a range of communicative functions in English (Sayer \& Ban, 2014). Quite similarly, Gao et al. (2014) reported that English was offered as a compulsory subject in primary schools in 2001 and pedagogical initiatives such as communicative language teaching and task-based instruction have been promoted as part of curriculum reforms at all educational levels in China (p. 57). Lastly, Ramjoo and Barabadi (2015) acknowledge that the Ministry of Education in Iran has initiated some changes in English education with the introduction of new textbooks which advocate a communicative approach to English teaching in 2013.

\section{EFL curriculum revision in Turkey}

English has been offered as a compulsory subject in primary and/ or secondary education programmes in Turkey since early 1990s. The Ministry of National Education (MoNE) introduced an educational reform (Primary Education Law, Act N. 6287), in March 2012 in accordance with the general objectives of Turkish National Education as defined in Basic Law of the National Education (Act N. 1739). Based on the changes in English as a Foreign Language (EFL) education programme, the starting age to foreign language instruction was lowered from 9 to 7 , and weekly class hours were increased from 2 hours to $3 / 4$ hours in primary education. Thereby, 'early introduction of foreign language instruction from Grade 2 was expected to demonstrate a strong accumulative effect which in turn could impact on all subsequent learning in a positive way' (Altan, 2017, p. 768). Consequently, EFL curriculum for young learners was redesigned with the core focus on communicative skills (e.g. listening, spoken interaction and spoken production), and the latest draft of the programme was released on the official website of the Ministry of National Education (MoNE) in 2017. The revised document is roughly comprised of a general rationale, key competences and learning outcomes to be attained at the end of each academic year, suggested practices for testing and assessment of language skills, suggested contexts, tasks and assignments, and sample communicative functions and useful language items. As stated in the document, the new programme has been designed based on the principles and descriptors of the Common European Framework 
of Reference for Languages: Learning, Teaching, and Assessment (CEFR), and it emphasizes language use in an authentic communicative environment. Therefore, as cited in major philosophy of the programme, use of English is emphasized in classroom interactions of all types, supporting learners in becoming language users, rather than students of the language, as they work toward communicative competence (CoE, 2001). In a similar vein, general objectives of the programme were grounded on the Communicative Approach that entails use of the target language not only as an object of study, but as a means of interacting with others; the focus is not necessarily on grammatical structures and linguistic functions, but on authentic use of the language in an interactive context in order to generate real meaning (Larsen-Freeman \& Anderson, 2011; Richards, 2006). Furthermore, based on the requirements of CEFR-based foreign language programmes, the new EFL teaching programme is framed in terms of language skills which stand for objectives for each unit, linguistic realizations of those language skills by referring to grade and language proficiency and pedagogic dimensions, such as suggested contexts and tasks as well as sample assignments shaped by specific language strategy (O'Malley \& Chamot, 1990; Oxford, 1990, 1996). Pursuant to these changes and general programme requirements, students attending state primary schools in Turkey are introduced EFL in their second year, and expected to attain A2 proficiency level in English upon their graduation. Figure 1 displays a screenshot taken from the 2nd grade EFL curriculum.

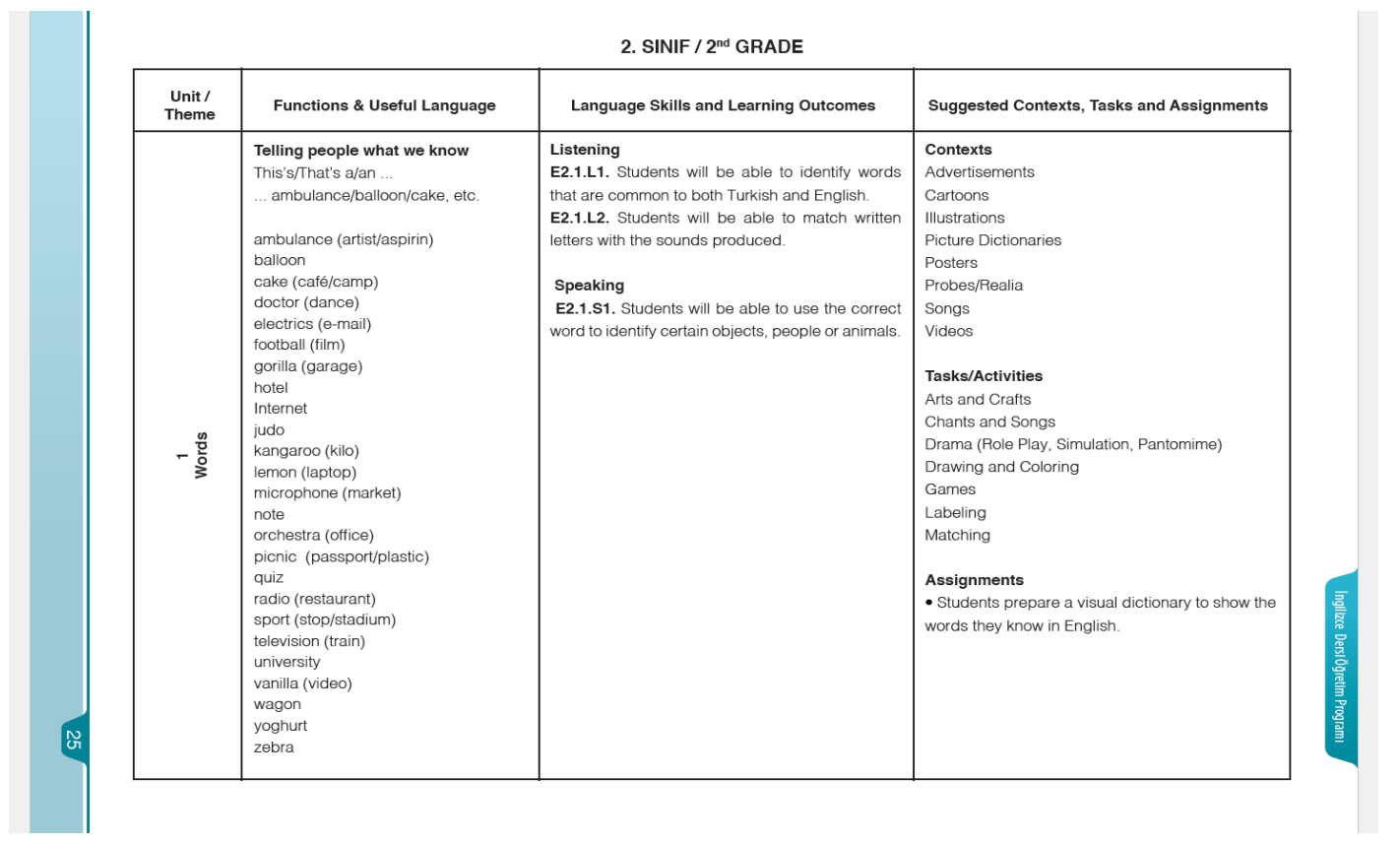

Figure 1. A page from 2nd grade EFL teaching programme

As seen in Figure 1, language skills, learning outcomes, and suggested assignments, which constituted the primary focus of the study, are identified for each unit. In the section of the curriculum structure, it is noted that 'that each objective specified in learning outcomes can be fulfilled merely by addressing the language functions and their linguistic realizations', and that 'teachers and material developers exploit the suggestions to provide students with a wide range of learning repertoire addressing different learning styles and strategies' (MoNE, 2017, p. 11). Nevertheless, it is considered beneficial to underline that English is taught as a foreign rather than a second language in Turkey. So, learning it in primary education is mostly restricted to three or four class hours at school unless the students have intrinsic motivation to spend time on it or they are motivated to do so by their parents/ siblings. Under such circumstances, attaining EFL proficiency is likely to become a challenge for them since they cannot recall the newly learnt language for a long time. Therefore, in order to bridge the gap between two weeks, and taking into consideration the major role 'contextualized and communicative homework plays in English language teaching' (Paudel, 2012 p. 56), the Turkish students are assigned certain tasks to reinforce the new language. In this respect, Kovalska and Prisyazhnyuk (2013) remark,

'A new challenge for a foreign language lecturer is the shift in emphasis in language teaching from a teacher-directed approach to a student-oriented one. Language learners must become more involved in managing their own learning (p. 65). It has been proved that most students are unlikely to learn everything they need to succeed in a class that meets for only a limited number of hours weekly' (p. 71).

Kumar (2006, p. 35-37) classified homework assignments into the following six categories: (i) practice type homework (to reinforce learning and help the student master specific skills), (ii) preparatory type homework (to introduce material that will be presented in future lessons), (iii) extension type homework (long-term continuing parallel class work), (iv) application type homework (enabling learners to establish a connection between skills and concepts with new concrete and abstract situations), (v) creative type homework (enabling learners to apply previously learned knowledge in a creative or imaginative manner), and (vi) cooperative type homework (enabling learners to work and learn cooperatively).

Keeping the aforementioned revisions and introductory statements in the newly revised curriculum in mind, the suggested assignments were predicted to fulfil the communicative objectives of the curriculum, and to fall more into the category of 
cooperative type assignments (Kumar, 2006), which require communication between and among students more than other categories. Hence, the current research was motivated to investigate the revised primary EFL curriculum with regard to communicative skills and suggested assignments identified for 2 nd to 8 th grades. It mainly concentrated on the distribution of the learning outcomes (LOs) across language skills to be attained for each grade in order to see whether communication skills are virtually emphasized over other skills such as reading, grammar and writing. Subsequently, it investigated to what extent suggested assignments serve the communicative purposes of the programme. Two research questions were constructed in line with the research objectives.

\section{Are communicative skills emphasized over other language skills in the revised primary EFL curriculum in Turkey?}

2. Do suggested assignments fulfil the communicative objectives of the revised primary EFL curriculum in Turkey?

The following section is intended to offer findings of previous research conducted on similar aspects of curriculum development/ revision as well as assignments in Turkey and abroad.

\section{Previous Research}

English Jin and Cortazzi (2002) informed that the communicative aspects of language learning were emphasized in the newly introduced English curricula in China by the 1980s (cited in Xiohong, 2009). Investigating the fundamentals of the revised EFL curriculum in 2003, Koç, Işıksal and Bulut (2007) found that the new programme 'promoted collaborative work and communication' (p. 31). Kırkgöz (2008) portrayed the revised EFL curriculum following the 1997 educational reform in Turkey as 'innovative for introducing the communicative language teaching approach to teaching English within the Turkish context where the teacher-centred style of teaching had predominated' (p. 311). Zhang (2012) reported that the national English curriculum introduced by the Chinese Ministry of Education in 2011 placed strong emphasis on oral communicative skills in EFL. Kırkgöz, Çelik and Arıkan (2014) indicated that the EFL program, which was revised based on the requirements of the 2005 educational reform in Turkey, 'was designed to encompass a communicative approach to language teaching, highlighting the forms and lexis of English in real life contexts in order to create relevance in learners' daily lives'. Yücel et al. (2017) analysed two and four EFL curricula for primary and secondary education, respectively in Turkey over the last 15 years. They indicated that curriculum design principles and the innovations in the field of language education were taken into consideration in the preparation of the programmes in concern. More specifically, they reported that the primary EFL curricula were compatible with the principles of curriculum design except for flexibility as they failed to satisfy the time proposed, and that the communicative approach was adopted in the latter but could not be completely understood and implemented by the teachers. Wiyono et al. (2017) revealed that implementing the communicative approach in language teaching did not significantly influence the students' learning outcomes in the national examination.

As for assignments, Wallinger (1997) concluded that students attending beginning-level foreign language classes tended to be given assignments that required more rote practice and allowed for only limited creative use of the language. In a more recent study, the researcher (2000) examined the role of homework in foreign language instruction and learning, and indicated that foreign language teachers at all levels felt strongly that homework is essential to language teaching and learning. In a similar fashion, Kovalska and Prisyazhnyuk (2013) conducted a longitudinal survey on home assignments with the participation of a group of Ukrainian university students and their lecturers at a technical university in Ukraine. They reported that the majority of the participating lecturers consider home assignment to be as important as the other class activities. Citing that communicative outof-class assignments facilitate learning through purposeful language use, Torres, Matamoros, Vargas and Pérez (2012) reported that 'communicative out-of-class tasks enhance learners' rate of response to homework assignments', that 'goal-oriented communicative tasks make students reflect on their own learning, and that homework complements the teaching and learning process when it fulfils the learners' interests and needs' (p. 229). Conducting a study with pre-service teachers, Yavuz (2015) reported that the participants were of the opinion that more interactive and communicative homework such as puzzles task-based project type homework should be assigned to students. The researcher also noted that pre-service teachers prefer homework that does not direct learners' attention to form such as grammar and structure but to the communicative aspects of language such as listening and speaking. Buga et al. (2014) probed the use of social media as a tool to improve communication competences of English and French learners in Romania. Accordingly, they created a Facebook account for a foreign language class where students' digital home assignments are displayed to stimulate more involvement in the learning activity, mainly in the writing assignments. They reported positive results such as that students who had never written their homework before started responding on Facebook to a variety of communicative assignments. Amiryousefi (2016) investigated views of Iranian EFL teachers and learners on different aspects of English homework, and concluded that homework as a part of out-of-class learning can have beneficial effects as long as it focuses on all English skills and sub-skills and based on students' needs and interests. In Japan, Yue (2016) carried out a longitudinal research with Japanese university students who were assigned to speak English after the communication classes as part of their homework, and reported that it was evaluated 'beneficial' by the students improving their fluency in the target language. Lastly, Sönmez-Ektem and Yıldız (2017) explored the role of the assignment in foreign language teaching based on teacher opinions, and revealed that most of the participants pay attention to give reinforcing homework assignments in order to improve secondary EFL students' literacy skills, grammar and vocabulary. 


\section{Method}

Data were compiled from EFL Teaching Programme redesigned by MoNE in Turkey, and announced on the official website of the ministry. More specifically, two sets of data were created to include a total of 376 intended learning outcomes (ILOs), and 124 suggested assignments identified in the programme. Data were analysed through document analysis method, a form of qualitative research in which documents are interpreted by the researcher to give voice and meaning around an assessment topic (Bowen, 2009), and which is particularly applicable to qualitative case studies -intensive studies producing rich descriptions of a single phenomenon, event, organisation, or program (Stake, 1995; Yin, 1994). In the current research, ILOs were initially tabulated for each grade, and classified into core language skills they are designed to improve: (i) listening, (ii) speaking, (iii) reading, and (iv) writing. Subsequently, the suggested assignments were analysed to reveal whether they are constructed to foster students' communicative competence in EFL. Each assignment was coded by the researchers as "communicative" and "noncommunicative", and the expert opinion was obtained from a faculty member specialised in curriculum and instruction during the data analysis process. The results obtained from data analysis are outlined in the following section.

\section{Findings}

Results of the data analysis have indicated that communicative skills (listening and speaking) are highlighted in the revised primary EFL teaching programme in Turkey. Namely, they constitute approximately $80 \%$ of all ILOs identified in the curricula for 2nd to 8th grades. Figure 2 and Figure 3 illustrate their distribution across core skills and that of skill-based ILOs across grades in the programme, respectively.

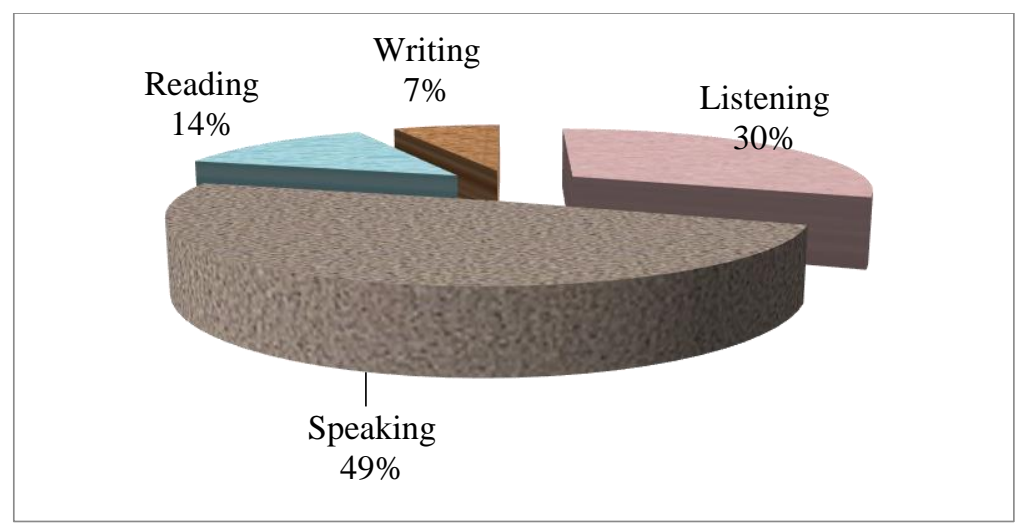

Figure 2. LOs across core skills in primary EFL teaching programme

As displayed in Figure 2, approximately half of the learning outcomes were designed to improve speaking skills of the students, followed by listening (30\%), reading (14\%) and writing (7\%). This finding seems to be in full agreement with the programme objectives. In other words, communicative skills (speaking and listening) proved the categories exclusively emphasized over reading and writing. Figure 3 demonstrates the distribution of the learning outcomes across core language skills and gra des in the revised curricula.

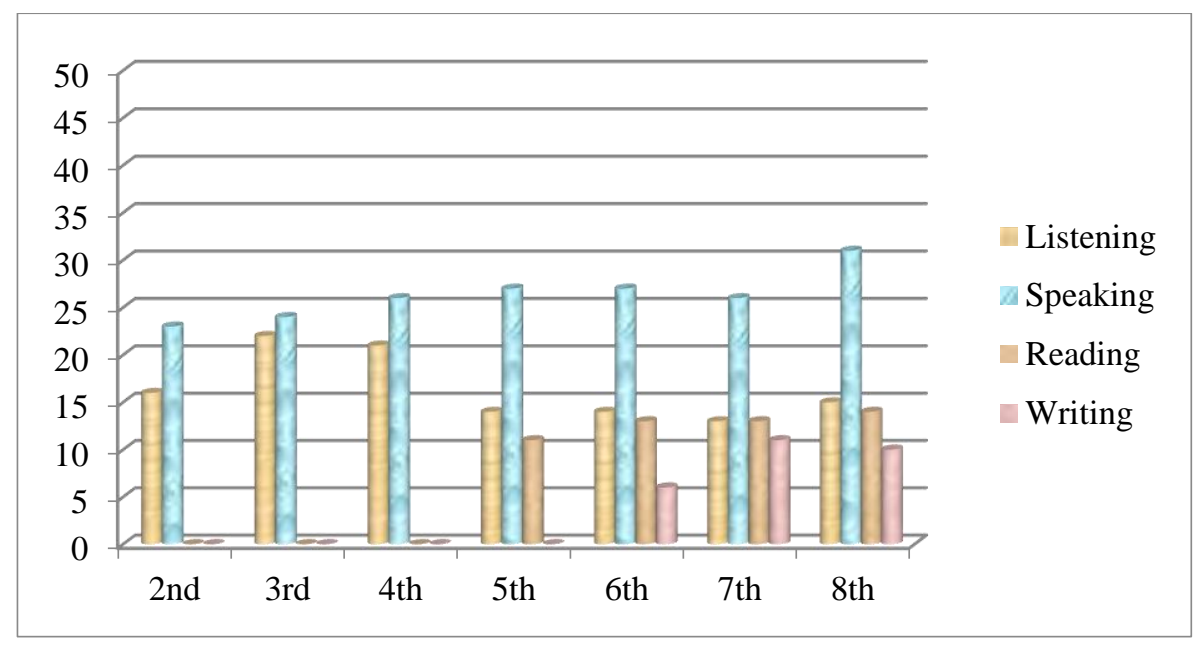

Figure 3. Skill-based LOs in primary EFL curriculum

As seen in Figure 3, the LOs were limited to speaking and listening skills during the first three grades of primary education (Grades 2, 3 \& 4), and that those concerning reading skill began to appear on EFL curriculum for 5th grade. Besides, the ILOs 
related to writing skill were not found in EFL curriculum till the second half of the 6th grade. The following were taken from each programme to exemplify the LOs in concern.

E2.2.S1. Students will be able to use everyday expressions for greeting and meeting someone. (Grade 2/ Speaking)

E3.5.L2. Students will be able to follow short and simple dialogues about possessions. (Grade 3/ Listening)

E4.3.S2. Students will be able to deliver a simple, brief speech about abilities with an initial preparation. (Grade 4/ Speaking)

E 5.1.R1. Students will be able to read picture stories, conversations and cartoons about personal information. (Grade 5/ Reading)

E6.6.W1. Students will be able to produce a piece of writing about occupations and the dates. (Grade 6/ Writing)

All in all, the findings driven from analysis of LOs confirmed that communicative skills received significantly more attention in primary EFL teaching programme than other language skills (e.g. reading and writing), which overlaps with the major philosophy of the revised programme, and the existing literature (Jin \& Cortazzi, 2002; Mackenzie, 2002; Mihai, 2003; Koç, Işıksal \& Bulut, 2007; Kırkgöz, 2008; Orafi \& Borg, 2009; Banegas, 2011; Zhang, 2012; Dubetz, 2014; Kırkgöz, Çelik \& Arıkan, 2014; Altan, 2017; Yücel et al., 2017). Moving from this particular finding, it was predicted that the suggested assignments would be grounded on pair work and group work which require students to work collaboratively/ cooperatively and to utilize communicative skills in the target language. However, the related results proved the opposite, as shown in Figure 4.

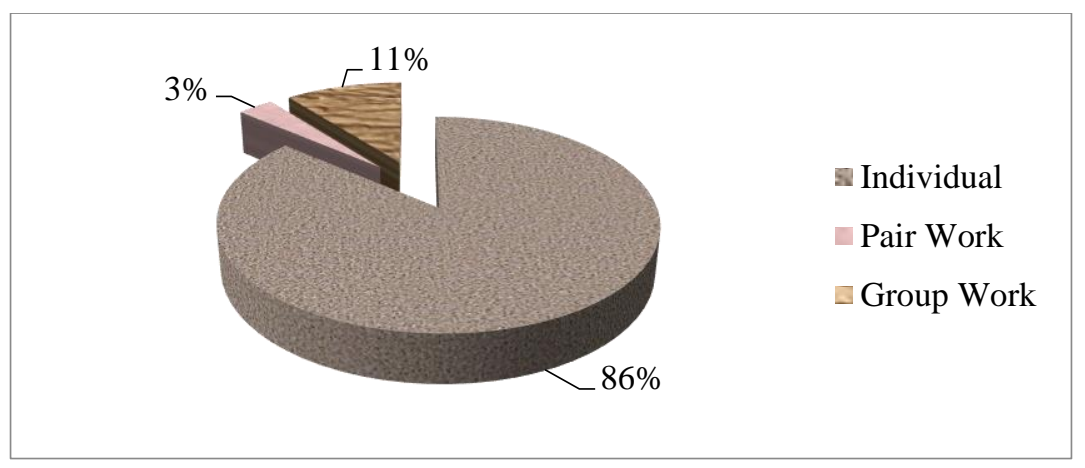

Figure 4. Suggested assignments in primary EFL teaching programme

As can be seen in Figure 4, the findings have demonstrated that less than $15 \%$ of the suggested assignments were designed to encourage collaboration/ cooperation among students, which entail the development of their communicative skills in EFL. Their distribution across grades is presented in Figure 5.

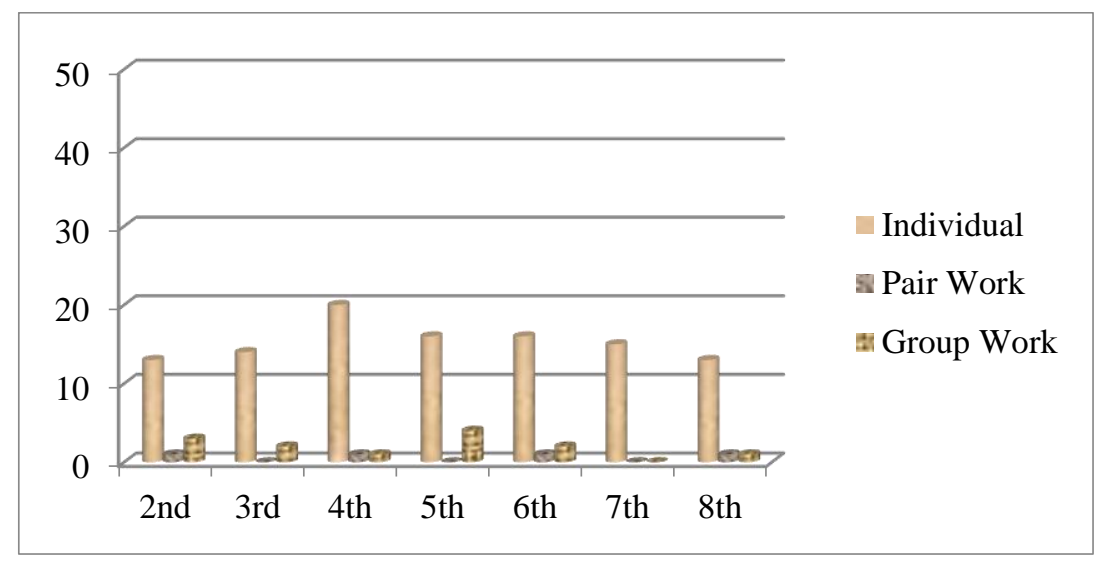

Figure 5. Nature of assignments in primary EFL teaching programme

As indicated in Figure 4 and Figure 5, three quarters of the assignments did not require collaboration/ cooperation among the students even though number of assignments that involve group work slightly increased 5th grade EFL curriculum. This finding largely coincides with Orafi (2008) who reported 'little evidence of core curricula principles such using pair work, and promoting the use of the target language among the students' in Libya' (p. 227). Besides, it was interesting to see that approximately $23 \%$ of the assignments was outlined as "Students keep expanding their visual dictionary by including new vocabulary items" regardless of the grades. This specific assignment could be evaluated as 'extension type homework' which involves long-term continuing parallel class work (Kumar, 2006). The findings in concern seems to be in line with Wallinger (1997), who informed beginner students in foreign language classes 'tended were mostly given assignments that required more rote practice and allowed for only limited creative use of the language'. 
When considering the overall distribution of the assignments in the revised programme, it could be concluded that $86 \%$ of the assignments involve the students' individual effort while $11 \%$ and $3 \%$ require collaboration/ cooperation between and among students, respectively. The assignments in concern were exemplified in the following.

Students prepare a poster to show their hobbies/games. (Grade 5/ Individual)

Students work in pairs. One student describes his/her favourite actor/singer and the other student draws a picture based on the description. (Grade 4/ Individual)

In groups, students make a survey to find out the favourite movies of their peers. (Grade 6/ Group work)

Lastly, the assignments in question were examined regarding their communicative nature. The statistical findings have revealed that $76 \%$ of them are non-communicative in nature, as indicated in Figure 6.

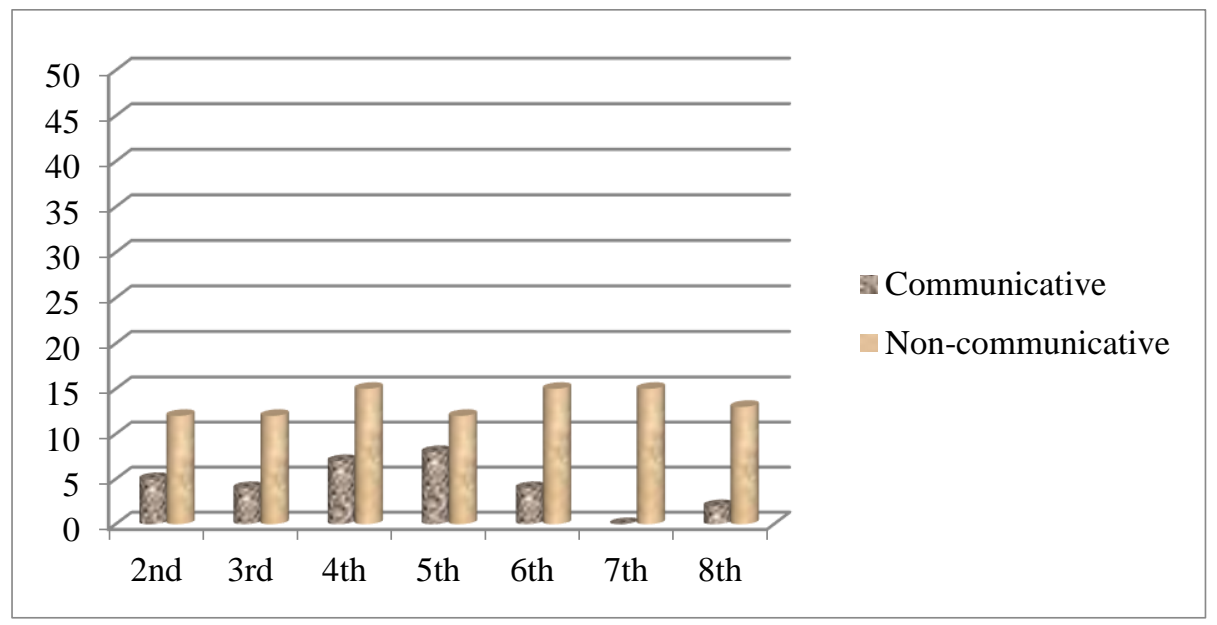

Figure 6. Nature of assignments in primary EFL teaching programme

As illustrated in Figure 6, communicative assignments relatively appeared in 2nd to 5th grade curricula; however, they slightly decreased and disappeared in 6th and 7th grades, respectively. Even though they slightly appeared in 8th grade curriculum, it could be concluded that they failed to fulfil the communicative objectives of the overall programme. This particular finding also conforms to Wallinger (1997), who revealed writing was five times more likely to be used than speaking, and seventeen times more likely to be used than listening and culture.

\section{Conclusions}

The current study was intended to scrutinize the revised primary EFL curriculum in Turkey with an exclusive focus on learning outcomes and suggested assignments described for 2 nd to 8 th grades. It mainly explored the compatibility between these two phenomena and the communicative objectives of the programme. The obtained findings have revealed that the majority of LOs were designed to improve communicative skills of the students (86\%). The suggested assignments, on the other hand, were evaluated non-communicative as more than $75 \%$ of them required individual rather than pair- and group work outside the classroom. Another striking finding of the study was that $23 \%$ of the suggested assignment was expressed with the very same statement regardless of grade and nature of subject: Students keep expanding their visual dictionary by including new vocabulary items. To put in a nutshell, the present study has indicated internal discrepancies in the revised curriculum in terms of its major philosophy and the nature of suggested assignments. This result largely complies with Oh and Johnson (2017).

In the light of the afore-mentioned research findings, EFL curriculum designers could be recommended to (re)design suggested assignments to improve students' communicative skills in the target language and to encourage collaboration/ cooperation between and among them by establishing and developing communication inside and outside the classroom. The following could be listed as recommendations for these assignments.

Existing assignment (Grade 2/ Unit 8: Pets)

Students draw the pet animals they have learnt to prepare posters and then display them on the classroom walls.

Recommended assignment: Students work in groups and prepare a poster with pet animals they have learnt and exchange information about the pet they like/ dislike.

Existing assignment (Grade 3/ Unit 9: Weather)

Students keep expanding their visual dictionary by including new vocabulary items.

Recommended assignment: Students work in pairs, ask each other how the weather was and try to visualise it. 
Existing assignment (Grade 5/ Unit 3: Games and Hobbies)

Students prepare a poster to show their hobbies/games.

Recommended assignment: Students work in pairs/groups, prepare a poster to show their hobbies/favourite games and talk about them using simple vocabulary.

Numerous other examples might be added to the above-mentioned suggestions for assignments. However, in the grand scheme of things, as cited in Gao et al. (2014), curriculum and pedagogy need to be supported by a collection of empirical studies rigorously conducted in a variety of educational settings. Hence, it could be suggested that the findings of such research as well as the views of teachers and students who stand at the very heart of teaching and learning process (Çetin \& Doğan, 2018) should be taken into consideration while (re)designing the relevant curricula.

\section{Suggestions for Further Directions}

This study was limited to the investigation of learning outcomes and suggested assignments in the revised primary EFL curriculum in Turkey regarding the communicative approach on which the main philosophy of the programme was constructed. Further studies might explore the revised secondary EFL curriculum in this respect. A similar study might evaluate CEFR-based EFL curricula implemented in other countries and compare its results in comparison to those reported here. The study was also confined to the employment of document analysis method; hence, it could be extended to obtain teachers' and/ students views on the suggested assignments. Lastly, future studies might focus on how to eliminate/ handle internal discrepancies of the revised EFL curriculum reported here.

\section{References}

Altan, M. Z. (2017). Globalization, English language teaching and Turkey. International Journal of Languages' Education and Teaching, 5(4), 764-776. DOI: 10.18298/ijlet.2238

Aksoy, E., Bozdoğan, D., Akbaş, U., \& Seferoğlu, G. (2018). Old wine in a new bottle: Implementation of intensive language program in the 5th grade in Turkey. Eurasian Journal of Applied Linguistics, 4(2), 301-324. DOI:10.32601/ejal.464187

Amiryousefi, M. (2016). Homework: Voices from EFL teachers and learners. Iranian Journal of Language Teaching Research, 4(2), 35-54. https://files.eric.ed.gov/fulltext/EJ1127366.pdf

Arıkan, A. (2017). English language teachers' views on the new national curriculum for $2^{\text {nd }}$ graders. Journal of Narrative and Language Studies, 5(9), 34-40. Retrieved from https://nalans.com/index.php/nalans/article/view/82

Banegas, D. L. (2011). Teachers as 'reform-doers': developing a participatory curriculum to teach English as a foreign language. Educational Action Research, 19(4), 417-432. https://doi.org/10.1080/09650792.2011.625654

Buga, R., CăpeneaĞă, I., Chirasnel, C., \& Popa, A. (2014). Facebook in foreign language teaching -a tool to improve communication competences. Procedia - Social and Behavioral Sciences, 128, 93-98. DOI: 10.1016/j.sbspro.2014.03.124

Canlıer, D., \& Tümen, N. T. (2018). Yabanci dil ağirlikli beşinci sinif İngilizce dersi öğretim programinin program tasarim ilkeleri açisindan analizi [Analysing $5^{\text {th }}$ grade English curriculum regarding curriculum design principles]. Pegem Atıf indeksi, North America. Retrieved from http://pegemindeks.net/index.php/Pati/article/view/3355 Date accessed: 19 Feb. 2019.

Council of Europe. (2001). Common European framework of reference for languages: Learning, teaching, assessment. Cambridge, U.K., Press Syndicate of the University of Cambridge.

Çetin, A., \& Doğan, A. (2018). Problems that mathematics teachers encounter in science and art centers. Ankara University Faculty of Educational Sciences Journal of Special Education, 19(4), 615-641. DOI:10.21565/ozelegitimdergisi.370355

Doğan, A., \& Çetin, A. (2018). Investigation of the perceptions of gifted students on the problem solving attitudes and processes. Cumhuriyet International Journal of Education, 7(4), 510-533. http://dx.doi.org/10.30703/cije.459434

Doğan, A., \& Yıldırım, G. (2019). The examination of BiLSEM students' happiness levels according to socio-demographic distribution (Example of Kahramanmaraş and Mersin provinces). In H. Şahin \& B. Avcı-Akbel (Eds.), Academic studies in educational sciences, (pp.73-91). IVPE: Cetinje.

Doğan, Y. (2010). Fen ve teknoloji dersi programinin uygulanmasi sürecinde karşilaşilan sorunlar [The problems encountered during the implementation of science and technology curriculum]. Yüzüncü Yıl Üniversitesi, Eğitim Fakültesi Dergisi, 7(1), 86-106. http://dergipark.ulakbim.gov.tr/yyuefd/article/view/5000055544

Dubetz, N. E. (2014). Studying the effects of an EFL curriculum for young adults in Brazil. English Language Teaching, 7(1), 103113. DOI: $10.5539 /$ elt.v7n1p103

Erdem, S., \& Yücel-Toy, B. (2017). Determination of the needs for foreign language oriented fifth grade English curriculum. Turkish Studies, 12(28), 259-280. http://dx.doi.org/10.7827/TurkishStudies.12346

Gao, X., Liao, Y., \& Li, Y. (2014). Empirical studies on foreign language learning and teaching in China (2008-2011): A review of selected research. Language Teaching, 47(1), 56-79. DOI: 10.1017/S0261444813000414

Jin, L., \& Cortazzi, M. (2002). English language teaching in China: A bridge to the future. Asia-Pacific Journal of Education, 22(2), 53-64.

Johnstone, R. 2009. An early start: What are the key conditions for generalized success? In J. Enever, J. Moon, \& U. Raman. (Eds.), Young Learner English Language Policy and Implementation: International Perspectives. Reading: Garnet Education, pp. 31-41. 
Kırkgöz, Y. (2008). Curriculum innovation in Turkish primary education. Asia-Pacific Journal of Teacher Education, $36(4), 309-322$. DOI: $10.1080 / 13598660802376204$

Kırkgöz, Y., Çelik, S., \& Arıkan, A. (2014). Designing an ELT curriculum for young Turkish learners: Pedagogical foundations, practical considerations, and procedures. Paper presented at the 1st Eurasian Educational Research Congress, Istanbul, Turkey.

Koç, Y., Işıksal, M., \& Bulut, S. (2007). Elementary school curriculum reform in Turkey. International Education Journal, 8(1), 3039. https://eric.ed.gov/?id=EJ841629

Kovalska, N., \& Prisyazhnyuk, N. (2013). Students' projects as home assignment. Bumyck, 2 , 65-71. http://visnyk.fl.kpi.ua/article/viewFile/30050/26782

Kumar, A. J. (2006). Homework education: A powerful tool of learning. Atlantic Publishers \& Distributors (P) Ltd.

Kurt, A. (2017). The evaluation of 4th grade English language curriculum by context, input, process, product model. Dicle University Journal of Ziya Gökalp Faculty of Education, 30, 508-524. http://dx.doi.org/10.14582/DUZGEF.1801

Larsen-Freeman, D., \& Anderson, M. (2011). Techniques and principles in language teaching (3 ${ }^{\text {rd }}$ Edition). New York, NY: Oxford University Press.

Mackenzie, A. S. (2002). EFL curriculum reform in Thailand. Curriculum Innovation, Testing and Evaluation: Proceedings of the 1st Annual JALT Pan-SIG Conference, May 11-12, 2002. Kyoto, Japan: Kyoto Institute of Technology. http://hosted.jalt.org/pansig/2002/HTML/Mackenzie1.htm

Mihai, F. M. (2003). Reforming English as a Foreign Language (EFL) Curriculum in Romania: The Global and the Local Contexts. Unpublished doctoral dissertation, The Florida State University, https://fsu.digital.flvc.org/islandora/object/fsu:180648/datastream/PDF/view

Oh, K., \& Johnson, D. (2017). The South Korean national curriculum for English: Problems of transparency and coherence. Korea TESOL Journal, 13(1), 3-32.

O'Malley, J. M., \& Chamot, A. U. (1990). Learning Strategies in Second Language Acquisition. Cambridge: Cambridge University Press.

O'Neill, G. (2010). Initiating curriculum revision: exploring the practices of educational developers. International Journal for Academic Development, 15(1), 61-71. DOI: 10.1080/13601440903529927

Orafi, S. M. S. (2008). Investigating Teachers' Practices and Beliefs in Relation to Curriculum Innovation in English Language Teaching in Libya. Unpublished doctoral dissertation, The University of Leeds, UK.

Orafi, S., \& Borg, S. (2009). Intentions and realities in implementing communicative curriculum reform. System, 37, $243-253$. https://doi.org/10.1016/j.system.2008.11.004

Oxford, R. L. (1990). Language Learning Strategies: What Every Teacher Should Know. Boston: Heinle \& Heinle.

Oxford, R. (1996). Language learning strategies around the world: Cross-cultural perspectives. University of Hawaii, Honolulu.

Paudel, J. (2012). Dealing with homework in English language teaching: A case of Dadeldhura district. Journal of NELTA, 17(1-2), 50-60.

Razmjoo, S. A., \& Barabadi, E. (2015). An activity theory analysis of ELT reform in Iranian public schools. Iranian Journal of Applied Linguistics, 18(1), 127-166. http://ijal.khu.ac.ir/article-1-2493-en.html

Richards, J. C. (2006). Communicative Language Teaching Today. Cambridge: Cambridge University Press.

Sayer, P., \& Ban, R. (2014). Young EFL students' engagements with English outside the classroom. ELT Journal, 68(3), $321-329$. https://doi.org/10.1093/elt/ccu013

Sönmez-Ektem, I., \& Yıldız, S. B. (2017). Teacher views about English homework. Journal of the Cukurova University Institute of Social Sciences, 26(3), 78-91. http://dergipark.gov.tr/cusosbil/issue/33225/369724

Stake, R. E. 1995. The art of case study research. London: Sage.

Strakšienè, G. (2011). Characteristics of the development of junior pupils' communicative competence at primary school. TILTAI, 1, 123-138.

Tezci, E. (2002). The Effects of Constructivist Instructional Design on the Success and Creativity of Fifth-Year Students in Primary Schools. Unpublished doctoral dissertation, Fırat University, Elazığ.

Torres, D. B., Matamoros, G. B., Vargas, J. R. S, \& Pérez, N. S. (2012). The increase in percentage of students who actually do homework by means of communicative out-of-class tasks instead of homework assignments: A case study of adult EFL students in the conversation courses at the University of Costa Rica. Revista de Lenguas Modernas, 16, $229-253$.

Wallinger, L. M. 1997. Foreign language homework from beginning to end: A case study of homework practices in foreign language classes. Unpublished manuscript, College of William and Mary at Williamsburg, VA.

Wallinger, L. M. (2000). The role of homework in foreign language learning. Foreign Language Annals, 33(5), $483-496$.

Wiyono, B. B., Gipayana, M., \& Ruminiati (2017). The influence of implementing communicative approach in the language teaching process on students' academic achievement. Journal of Language Teaching and Research, 8(5), 902-908. DOI: http://dx.doi.org/10.17507/jltr.0805.08

Xiohong, Z. (2009). A Great Leap Forward: EFL Curriculum, Globalization and Reconstructionism-A Case Study in North East China. Unpublished doctoral dissertation. University of Ballarat, Australia. https://mpra.ub.unimuenchen.de/30542/1/the_great_leap_forwrd_citatiom

Yavuz, F. (2015). Pre-service teachers' attitudes to foreign language teaching; change or status quo? Procedia-Social and Behavioral Sciences, 191, 1823-1827. DOI: 10.1016/j.sbspro.2015.04.226 
Yin, R. K. (1994). Case study research: Design and methods ( $2^{\text {nd }}$ Edition). Thousand Oaks, CA: Sage.

Yue, S. (2016). On speaking terms! Learners' views on an evolving out-of-class activity. The Bulletin of Central Research, 15(3), 4553.

Yücel, E., Dimici, K., Yıldız, B., \& Bümen, N. T. (2017). An analysis of the primary and secondary school English language curricula published over the last 15 years. Ege Eğitim Dergisi, 18(2): 702-737. DOI: 10.12984/egeefd.305922

Zhang, D. (2012). Chinese primary school English curriculum reform. In J. Ruan \& C. B. Leung (Eds.), Perspectives on Teaching and Learning English Literacy in China, Multilingual Education 3 (pp. 67-83). DOI: 10.1007/978-94-007-4994-8_5. 